\title{
Author Correction: Chemically triggered drug release from an antibody-drug conjugate leads to potent antitumour activity in mice
}

\author{
Raffaella Rossin ${ }^{1}$, Ron M. Versteegen², Jeremy Wu ${ }^{3}$, Alisher Khasanov ${ }^{4}$, Hans J. Wessels ${ }^{5}$, Erik J. Steenbergen ${ }^{6}$, \\ Wolter ten Hoeve ${ }^{7}$, Henk M. Janssen², Arthur H.A.M. van Onzen ${ }^{1}$, Peter J. Hudson ${ }^{3}$ \& Marc S. Robillard ${ }^{1}$
}

Correction to: Nature Communications; https://doi.org/10.1038/s41467-018-03880-y; published online 04 May 2018.

The original version of this Article omitted the following from the Acknowledgements: 'This work was supported by the Office of the Assistant Secretary of Defense for Health Affairs, through the Breast Cancer Research Program under Award No. W81XWH-15-10692. Opinions, interpretations, conclusions and recommendations are those of the author and are not necessarily endorsed by the Department of Defense'. This error has now been corrected in the PDF and HTML versions of the Article.

Published online: 16 January 2019

\begin{abstract}
(i) Open Access This article is licensed under a Creative Commons Attribution 4.0 International License, which permits use, sharing, adaptation, distribution and reproduction in any medium or format, as long as you give appropriate credit to the original author(s) and the source, provide a link to the Creative Commons license, and indicate if changes were made. The images or other third party material in this article are included in the article's Creative Commons license, unless indicated otherwise in a credit line to the material. If material is not included in the article's Creative Commons license and your intended use is not permitted by statutory regulation or exceeds the permitted use, you will need to obtain permission directly from the copyright holder. To view a copy of this license, visit http://creativecommons.org/licenses/by/4.0/.
\end{abstract}

(c) The Author(s) 2019

\footnotetext{
${ }^{1}$ Tagworks Pharmaceuticals, Geert Grooteplein Zuid 10, 6525 GA Nijmegen, The Netherlands. ${ }^{2}$ SyMO-Chem B.V., Den Dolech 2, 5612 AZ Eindhoven, The Netherlands. ${ }^{3}$ Avipep Pty Ltd, 343 Royal Parade, Parkville, VIC 3052, Australia. ${ }^{4}$ Levena Biopharma, 4955 Directors Place, Suite 300, San Diego, CA 92121, USA. ${ }^{5}$ Radboud Proteomics Centre, Department of Laboratory Medicine, Radboud University Medical Center, P.O. Box 91016500 HB Nijmegen, The Netherlands. ${ }^{6}$ Department of Pathology, Radboud University Medical Center, P.O. Box 91016500 HB Nijmegen, The Netherlands. ${ }^{7}$ Syncom B.V., Kadijk 3, 9747 AT Groningen, The Netherlands. Correspondence and requests for materials should be addressed to

M.S.R. (email: marc.robillard@tagworkspharma.com)
} 